DOI: $10.31933 / \mathrm{JIMT}$

Received: 23 Agustus 2020, Revised: 10 September 2020, Publish: 22 September 2020

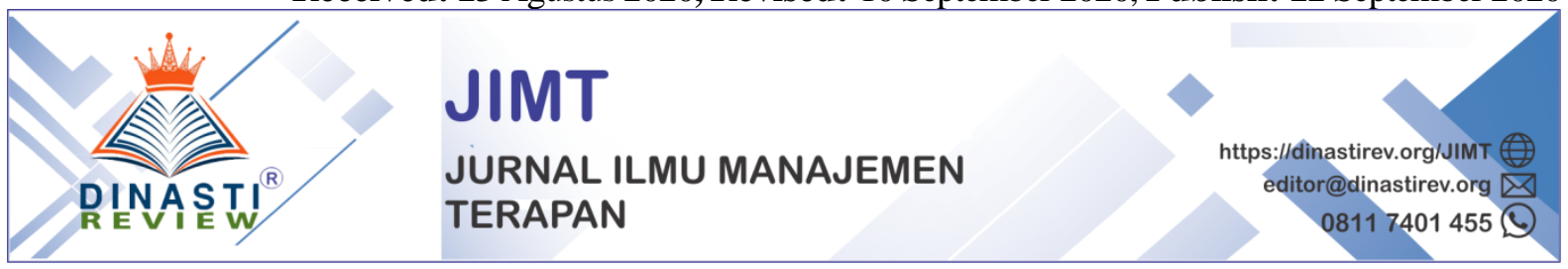

\title{
DETERMINASI MINAT BELI ONLINE SHOPEE
}

\author{
Ridho Rafqi Ilhamalimy ${ }^{1)}$ \\ ${ }^{1)}$ Universitas Mercu Buana, Jakarta, Indonesia, rafqiridho@gmail.com
}

\section{Corresponding Author: First Author}

\begin{abstract}
Abstrak: Pra riset ini dilakukan bertujuan untuk membangun hipotesis penelitian dengan menggunakan motode deskriptif. Untuk mengetahui variabel yang memepengaruhi Minat Beli Online, maka dilakukan review penelitian terdahulu. Hasil pra riset menunjukkan bahwa diduga $e$-WOM, Persepsi Risiko, Citra Merek, Kepercayaan memiliki hubungan baik secara langsung maupun tidak langsung terhadap Minat Beli Online.
\end{abstract}

Kata Kunci: Citra Merek, e-WOM, Kepercayaan, Minat Beli, Persepsi Risiko.

\section{PENDAHULUAN}

Konsumen yang aktif menggunakan aplikasi seluler dan jejaring sosial merupakan bentuk perilaku konsumen online dalam hal mengumpulkan informasi yang cendrung menimbulkan minat pembelian secara online (Kristiani et al., 2019). Perilaku konsumen online dalam mencari informasi produk menunjukkan kecenderungan untuk memiliki minat dalam membeli sebelum memutuskan melakukan pembelian (Han et al., 2018). Telah banyak penelitian terdahulu mengkaji faktor-faktor yang mempengaruhi niat beli online. Niat beli online dipengaruhi oleh kepercayaan selebriti, keahlian selebriti, daya tarik selebriti (Murwaningtyas et al. 2019), kemudahan dan kualitas produk (Indrajaya \& Ali, 2017), eWOM (Abubakar \& Ilkan, 2016; Jalilvand et al., 2017), publik relation dan iklan yang merupakan bagian dari promosi bisa meningkatkan minat pembelian secara online (Munawar \& Ali, 2017). Niat beli online juga dipengaruhi oleh persepsi risiko (Ariffin et al., 2018), kepercayaan (Farivar et al., 2017), dan citra merek (Agussalim \& Ali, 2017; Setyadi \& Ali, 2017; Ali, 2017).

Manfaat sosial dan kepercayaan mempengaruhi minat beli online (Liu \& Guo, 2017). Pudaruth \& Nursing, (2017) menemukan kemudahan mempengaruhi niat beli. Penelitian yang dikembangkan oleh (Silva et al., 2019) bahwa kepercayaan memiliki kemampuan dalam memdiasi risiko yang dirasakan terhadap minat beli online, kemudian dari perspektif yang berbeda kepercayaan juga mampu memediasi e-wom terhadap minat beli online (Bhandari \& Rodgers, 2018). Penelitian (Silva et al., 2019) sebelumnya menjadikan variabel kepercayaan sebagai mediasi antara persepsi risiko dan ewom terhadap minat beli online, dan dari perspektif yang berbeda (Bhandari \& Rodgers, 2018) menemukan bahwa variabel kepercayaan mampu memediasi antara $e$-wom terhadap minat beli online. 
Dalam menyusun artikel peneliti yang relevan di perlukan beberapa teori untuk memperkuat model penelitian yang dibangun dan melihat hubungan antar variabel dalam membangun hipotesis merupakan bagian pembahasan hasil penelitian. Artikel ini khsusus membahas faktor-faktor yang mempengaruh minat beli konsumen, dimana studi ini merupakan studi literaturmanajmen pemasaran. Tentu tidak semua faktor yang mempengaruhi minat beli pada artikel ini, namun sebagian faktor-faktor dominan saja yang akan di kaji pada atikel ini.

\section{Rumusan Masalah}

Berdasarakan latar belakang yang telah diuraikan di atas, maka di rumuskan masalah yang akan di bahas untuk lebih fokus pada kajian pustaka, hasil dan pembahasan adalah untuk mereview teori pengaruh variabel independent terhadap variabel dependent seperti tertera di bawah ini:

1) Apakah EWOM memiliki hubungan dan berpengaruh terhadap Kepercayaan?

2) Apakah EWOM memiliki hubungan dan berpengaruh terhadap Minat Beli?

3) Apakah Citra Merek memiliki hubungan dan berpenagruh terhadap Kepercayaan?

4) Apakah Citra Merek memiliki hubungan dan berpenagruh terhadap Minat Beli?

5) Apakah Persepsi Risiko memiliki hubungan dan berpenagruh terhadap Kepercayaan?

6) Apakah Persepsi Risiko memiliki hubungan dan berpenagruh terhadap Minat Beli?

7) Apakah Kepercayaan memiliki hubungan dan berpenagruh terhadap Minat Beli?

8) Apakah Kepercayaan Memediasi eWOM dengan Minat Beli?

9) Apakah Kepercayaan Memediasi Citra Merek dengan Minat Beli?

10) Apakah Kepercayaan Memediasi Persepsi Risiko dengan Minat Beli?

\section{KAJIAN PUSTAKA \\ Minat Beli}

Minat beli merupakan sesuatu yang timbul setelah menerima rangsangan dari produk yang dilihatnya, kemudian muncul keinginan untuk membeli dan memilikinya (Kotler \& Amstrong, 2012). Penelitian tentang Minat Beli telah banyak dikaji oleh penelitian sebelumnya seperti penelitian yang dikembangkan oleh (Abubakar \& Ilkan, 2016), (Erkan \& Evans, 2016), (Bataineh, 2015), (Lee et al., 2017), (Agussalim \& Ali, 2017), (Setyadi \& Ali, 2017), (Ali, 2017), (Farivar et al., 2017), (Silva et al., 2019), (Ho et al., 2017), (Larasetiati \& Ali, 2019), (Firmansyah \& Ali, 2019), (Liu \& Guo, 2017), (Mosunmola et al., 2019), (Kaur \& Quareshi, 2015), (Marriott \& Williams, 2018), (Zhao et al., 2019), (Pappas, 2018), dan (Firmansyah \& Ali, 2019).

\section{EWOM}

eWOM merupakan suatu penyebaran informasi antar konsumen yang saling memberikan informasi melalui media internet (Schiffman \& Kanuk, 2012). Penelitian tentang EWOM telah banyak dikaji oleh penelitian sebelumnya seperti penelitian yang dikembangkan oleh (Abubakar \& Ilkan, 2016)), (Erkan \& Evans, 2016), (Bataineh, 2015), (Lee et al., 2017), (Bulut \& Karabulut, 2018), (Ali, 2019), (Matute et al., 2016), (Firmansyah \& Ali, 2019), dan (Bhandari \& Rodgers, 2018).

\section{Citra Merek}


Citra merek didefinisikan sebagai seperangkat keyakinan, ide, dan kesan yang dimiliki oleh seseorang terhadap suatu merek yang dapat mempengaruhi keputusan seseorang (Levy \& Weitz, 2012). Penelitian tentang Citra Merek telah banyak dikaji oleh penelitian sebelumnya seperti penelitian yang dikembangkan oleh (Ali, 2017), (Agussalim \& Ali, 2017), (Setyadi \& Ali, 2017), (Ali, 2019), (Firmansyah \& Ali, 2019).

\section{Persipsi Risiko}

Persepsi risiko merupakan ketidakpastian yang dihadapi saat konsumen tidak dapat memprediksi konsekuensi dalam melakukan keputusan pembelian. Hal ini menekankan bahwa konsumen dipengaruhi oleh risiko yang dipersepsikan, tanpa mempedulikan apakah risiko itu ada atau tidak. Tidak adanya resiko yang dipersepsi oleh konsumen akan mempengaruhi perilaku konsumen (Schiffman \& Kanuk, 2012). Penelitian tentang Persepsi Risiko telah banyak dikaji oleh penelitian sebelumnya seperti penelitian yang dikembangkan oleh (Farivar et al., 2017), (Silva et al., 2019), (Ho et al., 2017), (Kamalul Ariffin et al., 2018), (Hamid et al., 2016), (Pudaruth \& Nursing, 2017; Wingate, 2019), (Gunawan \& Huarng, 2015), (Pappas, 2016), (Park et al., 2019), dan (Yang et al., 2015).

\section{Kepercayaan}

Kepercayaan konsumen didefinisikan sebagai pengetahuan yang dimiliki konsumen dari kesimpulan yang dibuat tentang objek, atribut, dan manfaatnya (Mowen, 2012). Penelitian tentang Kepercayaan telah banyak dikaji oleh penelitian sebelumnya seperti penelitian yang dikembangkan oleh (Larasetiati \& Ali, 2019), (Firmansyah \& Ali, 2019), (Liu \& Guo, 2017), (Mosunmola et al., 2019), (Kaur \& Quareshi, 2015), (Marriott \& Williams, 2018), (Zhao et al., 2019), (Pappas, 2018), (Firmansyah \& Ali, 2019), (Ali, 2019), (Agussalim \& Ali, 2017), (Ali, 2019), (Farivar et al., 2017), (Silva et al., 2019), ((Ho et al., 2017), (Pappas, 2016), (Park et al., 2019), (Yang et al., 2015), (Bulut \& Karabulut, 2018), (Ali, 2019), (Matute et al., 2016), dan (Bhandari \& Rodgers, 2018).

\section{METODE PENELITIAN}

Metode penulisan artikel ilmiah ini menggunakan studi literatur dan studi kepustakaan. Dengan mengkaji berbagai referensi sesuai dengan teori yang dibahas, khusunya dalam lingkup Manajemen Pemasaran. Disamping itu menganalisis artikel-artikel ilmiah yang bereputasi dan juga artikel ilmiah dari jurnal yang belum bereputasi. Semua artikel ilmiah yang di citasi bersumber dari Mendeley dan Scholar Google.

Dalam penelitian kualitatif, kajian pustaka harus digunakan secara konsisten dengan asumsi-asumsi metodologis. Artinya harus digunakan secara induktif sehingga tidak mengarahkan pertanyaan-pertanyaan yang diajukan oleh peneliti. Salah satu alasan utama untuk melakukan penelitian kualitatif yaitu bahwa penelitian tersebut bersifat eksploratif, (Ali \& Limakrisna, 2013).

Selanjutnya dibahas secara mendalam pada bagian yang berjudul" Pustaka Terkait" (Related Literature) atau Kajian pustaka( "Review of Literature"), sebagai dasar perumusan hipotesis dan selanjutnya akan menjadi dasar untuk melakukan perbandingan dengan hasil atau temuan-temuan yang terungkap dalam penelitian, (Ali \& Limakrisna, 2013). 


\section{HASIL DAN PEMBAHASAN}

\section{1. $E W O M$ dan Kepercayaan}

Model penelitian yang di kembangkan oleh (Bulut \& Karabulut, 2018) menyatakan bahwa kualitas $e W O M$ dan kuantitas $e W O M$ memiliki positif pengaruh pada $e$-trust. Ali, (2019) kepercayaan konsumen dapat meningkat dengan adanya aktivitas promosi, seperti media sosial, koran, papan iklan, eWOM dan iklan TV. Dikarenakan $e W O M$ secara positif (Abubakar \& Ilkan, 2016) dan (Matute et al., 2016) signifikan mempengaruhi kepercayaan. Kepercayaan merupakan gambaran perilaku pembelian terhadap produk yang dapat dianggap sebagai keunggulan kompetitif perusahaan di masa depan (Firmansyah \& Ali, 2019).

\section{EWOM dan Minat Beli}

Word of Mouth Marketing dapat sangat berpengaruh terhadap proses keputusan pembelian (Kotler \& Keller, 2013). eWOM merupakan peroses pertukaran informasi yang dinamis dan berkelanjutan antara konsumen potensial, aktual atau pengalaman mengenai suatu produk, layanan, merek atau perusahaan, yang tersedia untuk banyak orang dan lembaga melalui internet (Ismagilova et al., 2017). Rekomendasi dari pelanggan lain biasanya dianggap lebih dipercaya ketimbang kegiatan promosi yang berasal dari prusahaan dan dapat sangat mempengaruhi keputusan orang lain untuk menggunakan suatu produk atau jasa (Lovelock, 2011).penelitian yang dilakukan oleh (Abubakar \& Ilkan, 2016) menyatakan bahwa E-wom dapat mempengaruhi minat beli. (Erkan \& Evans, 2016) ewom memiliki pengaruh positif dan signifikan terhadap minat beli. (Bataineh, 2015) menemukan bahwa kualitas $e W O M$, kredibilitas $e W O M$, dan kuantitas $e W O M$ berpengaruh terhadap minat beli.

\section{Citra Merek dan Kepercayaan}

Kuatnya citra merek di benak konsumen akan menyebabkan semakin meningkatnya kepercayaan yang dirasakan konsumen dalam menggunakan produk yang dibelinya (Agussalim \& Ali, 2017). Ketika konsumen sadar terhadap merek yang akan digunakan memiliki manfaat lebih, konsumen akan percaya (Ali, 2019), karena citra merek dan reputasi perusahaan yang dapat dipertahankan, akan menimbulkan perilaku pembelian (Ali, 2019). Citra merek memiliki aspek yang dapat dibentuk melalui akses layanan, layanan yang ditawarkan, kontak pribadi, keamanan, dan reputasi psoitif dapat mepengaruhi kepercayaan dan komitmen konsumen (Setyadi \& Ali, 2017). Citra merek secara signifikan mempengaruhi kepercayaan diterima oleh konsumen (Cheong \& Jang, 2008).

\section{Citra Merek dan Minat Beli}

Faktor citra merek, kesadaran merek dan harga dapat mempengaruhi secara positif perilaku pembelian suatu produk (Ali, 2019). Dimana citra merek merupakan gambaran dari reputasi positif penjual yang ada di benak konsumen (Setyadi \& Ali, 2017). Citra merek yang kuat menandakan bahwa konsumen akan percaya terhadap produk yang dibelinya (Agussalim \& Ali, 2017). Citra merek untuk pembelian produk elektronik berkorelasi positif dan pengaruhnya signifikan terhadap minat beli (Kazmi \& Mehmood, 2016). Adapun penelitian oleh (Yu et al., 2013) menemukan adanya pengaruh positif antara citra merek dengan niat beli. 


\section{Persepsi Risiko dan Kepercayaan}

Persepei risiko yang dirasakan memiliki pengaruh negatif signifikan terhadap niat pembelian online (Kamalul Ariffin et al., 2018). Penelitian yang dikembangkan oleh (Hamid et al., 2016) menemukan bahwa risiko yang dirasakan berdampak negatif pada niat pembelian konsumen online. Seprti halnya (Pudaruth \& Nursing, 2017; Wingate, 2019) juga menemukan resiko berpengaruh negatif dan signifikan terhadap niat pembelian. Berbeda dengan hasil penelitian oleh (Gunawan \& Huarng, 2015) yang menemukan bahwa persepsi resiko berpengaruh positif dan signifikan terhdap niat beli.

\section{Persepsi Risiko dan Minat Beli}

Persepsi risiko didefinisikan sebagai ketidakpastian yang dihadapi ketika konsumen tidak dapat memprediksi konsekuensi saat melakukan keputusan pembelian. Walaupun tidak adanya resiko yang dipersepsi oleh konsumen tetap akan mempengaruhi perilaku konsumen (Schiffman \& Kanuk, 2012). Persepsi risiko juga sebagai cara konsumen mempersepsikan kemungkinan kerugian yang akan diperoleh dari keputusannya sebagai akibat dari ketidakpastian dari hal yang diputuskan tersebut. Suryani (2013) resiko yang dipersepsikan didefinisikan sebgai ketidakpastian yang dihadapi konsumen ketika mereka tidak mampu melihat kemumgkinan yang terjadi akibat keputusan pembelian yang dilakukan. Penelitian yang dikembangkan oleh (Farivar et al., 2017) menyatakan bahwa ketika konsumen percaya terhadap suatu produk, maka akan mengurangi risiko yang dirasakan. Silva et al., (2019) kepercayaan berpengaruh negatif terhadap persepsi resiko yang dirasakan. Adapun Ho et al., (2017) risiko yang dirasakan memiliki efek signifikan terhadap kepercayaan kepercayaan konsumen.

\section{Kepercayaan dan Minat Beli}

Kepercayaan konsumen merupakan pengetahuan yang dimiliki oleh konsumen dan semua kesimpulan yang dibuat konsumen tentang objek, atribut, dan manfaatnya (Mowen, 2012). Ketika konsumen memiliki keyakinan pada pihak lain yang terlibat dalam pertukaran informasi uang reliabilitas dan integritas, maka dapat dikatakan ada kepercayaan (Kotler dan Keller, 2013). Kepercayaan konsumen terhadap berbagai sumber informasi, konsumen mengungkapkan bahwa komunikasi yang di rekomendasikan akan berjalan dengan sendirinya menjadi sumber informasi yang paling terpercaya (Schiffman \& Kanuk, 2012). Penelitian yang dikembangkan oleh (Larasetiati \& Ali, 2019) bahwa kepercayaan konsumen akan menciptakan kepercayaan yang baik pada penjual dan akan meningkatkan konsumen dalam perilaku pembelian. Kepercayaan memiliki efek langsung dan signifikan terhadap niat beli (Firmansyah \& Ali, 2019). Seperti halnya (Liu \& Guo, 2017) bahwa kepercayaan secara positif memengaruhi niat beli. Mosunmola et al. (2019) juga menemukan adanya pengaruh antara kepercayaan dengan minat beli. Kemudian hasil penelitian (Kaur \& Quareshi, 2015; Marriott \& Williams, 2018) menemukan faktor kepercayaan berpengaruh positif dan signifikan terhadap minat beli. Pelanggan memliki niat beli berkelanjutan ketika mereka mempercayai penjual (Zhao et al., 2019) dan kepercayaan merupakan faktor penting dalam meningkatkan minat belanja online (Pappas, 2018), karena minat beli merupakan kunci keberhasilan e-commerce (Firmansyah \& Ali, 2019). 


\section{Kepercayaan, $E W O M$ dan Minat Beli}

Hubungan antara ewom dengan minat beli yang dimediasi oleh kepercayaan di kembangkan oleh (Abubakar \& Ilkan, 2016) menemukan bahwa eWOM online secara positif mempengaruhi kepercayaan dan mepengaruhi niat pembelian. Seperti halnya penelitian yang dilakukan oleh (Bhandari \& Rodgers, 2018) juga menemukan adanya pengaruh positif antara eWOM dengan minat beli yang dimediasi oleh keprcayaan. Adapun hasil temuan (Matute et al., 2016) menunjukkan bahwa eWOM memiliki efek positif secara langsung dan secara tidak langsung mempengaruhi niat pembelian melalui kepercayaan.

\section{Kepercayaan, Citra Merek dan Minat Beli}

Secara umum, kepercayaan konsumen dipandang sebagai niat baik penjual, keahlian dan kejujuran. Dengan mempertahankan kepercayaan konsumen, maka akan menciptakan perilaku pembelian di masa mendatang (Firmansyah \& Ali, 2019). Ketika konsumen sadar terhadap merek yang akan digunakan memiliki manfaat lebih, konsumen akan percaya (Ali, 2019), karena reputasi perusahaan yang baik menimbulkan perilaku pembelian (Ali, 2019). Seperti halnya penelitian yang dikemnbangkan oleh (Cheong \& Jang, 2008) bahwa citra merek secara signifikan mempengaruhi kualitas dan kepercayaan diterima oleh konsumen, dimana secara keseluruhan, kepercayaan memainkan peran pentin dalam meningkatkan nilai pelanggan jangka panjang dalam dinamika minat beli online. Penelitian oleh (Yu et al., 2013) menemukan bahwa citra merek memiliki dampak positif pada niat beli.

\section{Kepercayaan, Persepsi Risiko dan Minat Beli}

Penelitian yang dikembangkan oleh (Farivar et al., 2017) bahwa risiko memliki pengaruh negatif signifikan terhadap niat membeli dan kepercayaan memiliki pengaruh positif terhadap niat beli. Selain itu, kepercayaan dapat mengurangi risiko yang dirasakan, sehingga menimbulkan minat beli. Sama halnya dengan penelitian (Silva et al., 2019) menemukan bahwa kepercayaan pada lingkungan online dipengaruhi secara negatif oleh persepsi resiko, dimana mempengaruhi juga perilaku pembelian online. (Ho et al., 2017) menunjukkan bahwa risiko yang dipersepsikan memiliki efek signifikan terhadap kepercayaan, yang mengarah pada keputusan pembelian. Adapun penelitian yang di kembangkan (Pappas, 2016), (Park et al., 2019), dan (Yang et al., 2015) bahwa persepsi resiko terhadap kepercayaan berpengaruh negatif signifikan minat beli.

\section{Pra Riset}

Untuk lebih memperkuat hubungan antar variabel yang telah di bahas sebelumnya, dilakukanlah pra riset. Pemilihan variabel-variabel yang digunakan dalam melakukan pra riset merupakan variabel-variabel yang relevan dengan objek yang diteliti. Diantara variabelvariabel yang dipilih, meliputi persepsi risiko, desain aplikasi, kemudahan, kepercayaan, manfaat sosial, ewom, celebrity endoresr, dan citra merek. Berikut dapat dilihat hasil pra riset tentang minat beli online pada Tabel berikut ini. 
Tabel 1. Hasil Pra Riset Minat Beli online

\begin{tabular}{|c|c|c|c|}
\hline No & $\begin{array}{r}\text { Variabel } \\
\end{array}$ & Jumlah & Persentase \\
\hline 1 & Persepsi resiko & 15 & 0,17 \\
\hline 2 & Desain aplikasi & 7 & 0,08 \\
\hline 3 & Kemudahan & 10 & 0,11 \\
\hline 4 & Kepercayaan & 13 & 0,15 \\
\hline 5 & Manfaat sosial & 8 & 0,09 \\
\hline 6 & $e$-wom & 16 & 0,18 \\
\hline 7 & Celebrity endorser & 5 & 0,05 \\
\hline 8 & Citra merek & 11 & 0,12 \\
\hline & Total & 85 & 0.95 \\
\hline
\end{tabular}

Sumber : Hasil Pra Riset 2020

Berdasarkan diskusi dan hasil pra survei di atas, faktor-faktor yang mendominasi dalam mempengaruhi minat beli online, melitputi persepsi risiko, kepercayaan, eWOM, dan citra merek.

\section{Rerangka Konseptual}

Berdasarkan Kajian teori dan hubungan antar variabel maka model atau Conceptual Framework artikel ini dalam rangka menbagunan hipotesis adalah sebagai berikut:

1) EWOM memiliki hubungan dan berpengaruh terhadap Kepercayaan, ini berdasarkan hasil riset diantaranya adalah: (Toto Handiman \& Ali, 2019), (Indarsin \& Ali, 2017), (Matute et al., 2016).

2) EWOM memiliki hubungan dan berpengaruh terhadap Minat Beli, ini berdasarkan hasil riset diantaranya adalah: (Desfiandi et al., 2017), (Lovelock, 2011).

3) Citra Merek memiliki hubungan dan berpenagruh terhadap Kepercayaan, ini berdasarkan hasil riset diantaranya adalah: (Ali et al., 2016), (M \& Ali, 2017), (Ali \& Mappesona, 2016), (Ali et al., 2018), (Novansa \& Ali, 1926), (Toto Handiman \& Ali, 2019), (Toto Handiman \& Ali, 2019), dan (Indarsin \& Ali, 2017), (Cheong \& Jang, 2008).

4) Citra Merek memiliki hubungan dan berpenagruh terhadap Minat Beli, ini berdasarkan hasil riset diantaranya adalah: (Ali et al., 2016), (M \& Ali, 2017), (Ali \& Mappesona, 2016), (Ali et al., 2018), (Novansa \& Ali, 1926), (Toto Handiman \& Ali, 2019), dan (Desfiandi et al., 2017), (Kazmi \& Mehmood, 2016).

5) Persepsi Risiko memiliki hubungan dan berpenagruh terhadap Kepercayaan, ini berdasarkan hasil riset diantaranya adalah: (Toto Handiman \& Ali, 2019), (Indarsin \& Ali, 2017), Wingate, 2019).

6) Persepsi Risiko memiliki hubungan dan berpenagruh terhadap Minat Beli, ini berdasarkan hasil riset diantaranya adalah: (Desfiandi et al., 2017), Silva et al., (2019).

7) Kepercayaan memiliki hubungan dan berpenagruh terhadap Minat Beli, ini berdasarkan hasil riset diantaranya adalah: (Toto Handiman \& Ali, 2019), (Indarsin \& Ali, 2017), dan (Desfiandi et al., 2017), (Liu \& Guo, 2017).

8) Kepercayaan Memediasi eWOM dengan Minat Beli, ini berdasarkan hasil riset diantaranya adalah: (Toto Handiman \& Ali, 2019), (Indarsin \& Ali, 2017), dan (Desfiandi et al., 2017), (Matute et al., 2016). 
9) Kepercayaan Memediasi Citra Merek dengan Minat Beli, ini berdasarkan hasil riset diantaranya adalah: (Toto Handiman \& Ali, 2019), (Indarsin \& Ali, 2017), (Yu et al., 2013).

10) Kepercayaan Memediasi Persepsi Risiko dengan Minat Beli, ini berdasarkan hasil riset diantaranya adalah: (Ali et al., 2016), (M \& Ali, 2017), (Ali \& Mappesona, 2016), (Ali et al., 2018), (Novansa \& Ali, 1926), (Toto Handiman \& Ali, 2019), (Desfiandi et al., 2017), (Yang et al., 2015).

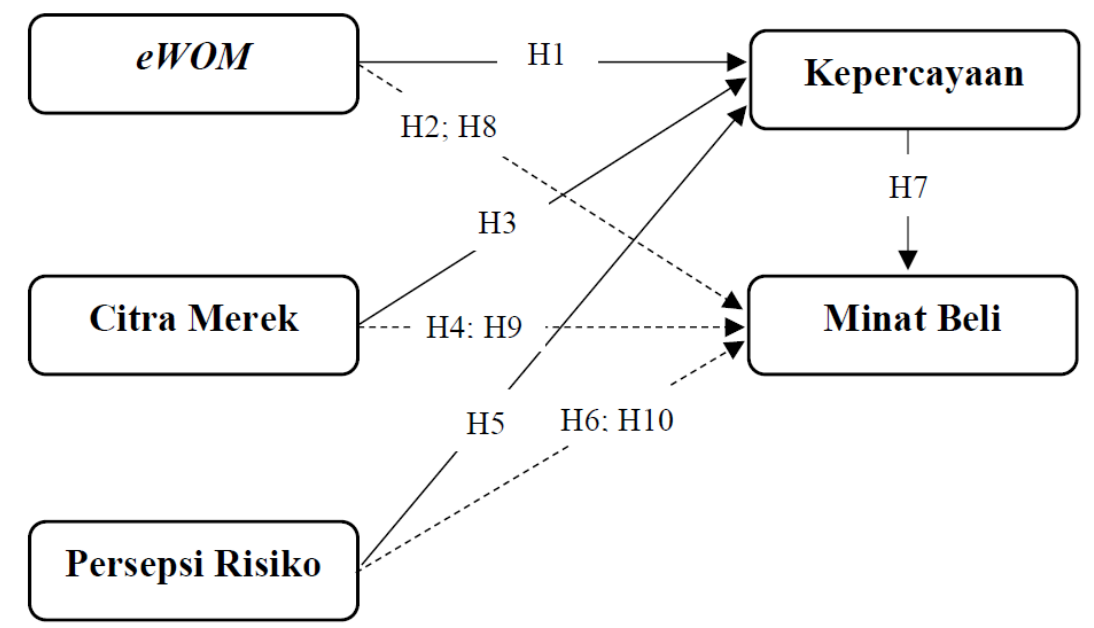

Gambar 1. Rerangka Konseptual

\section{KESIMPULAN DAN SARAN \\ Kesimpulan}

Berdasarkan rumusan artikel, hasil dan pembahasan yang di kaji dan di bahas pada artikel ini, maka dapat disimpulkan untuk membangun suatu hipoteis guna untuk riset selanjutnya adalah:

11) EWOM memiliki hubungan dan berpengaruh terhadap Kepercayaan.

12) EWOM memiliki hubungan dan berpengaruh terhadap Minat Beli.

13) Citra Merek memiliki hubungan dan berpenagruh terhadap Kepercayaan.

14) Citra Merek memiliki hubungan dan berpenagruh terhadap Minat Beli.

15) Persepsi Risiko memiliki hubungan dan berpenagruh terhadap Kepercayaan.

16) Persepsi Risiko memiliki hubungan dan berpenagruh terhadap Minat Beli.

17) Kepercayaan memiliki hubungan dan berpenagruh terhadap Minat Beli.

18) Kepercayaan Memediasi $e$ WOM dengan Minat Beli.

19) Kepercayaan Memediasi Citra Merek dengan Minat Beli.

20) Kepercayaan Memediasi Persepsi Risiko dengan Minat Beli.

\section{Saran}

Bersdasarkan Kesimpulan di atas, maka saran pada artikel ini baik secara akademik atau secara empirik adalah masih banyak faktor lain yang mempengaruhi Minat Beli Konsumen. Oleh karena itu, masih di perlukan kajian yang lebih lanjut untuk melengkapi faktor-faktor lain apa sajakah yang dapat memepengaruhi Minat Beli. 


\section{DAFTAR RUJUKAN}

Abubakar, A. M., \& Ilkan, M. (2016). Impact of online WOM on destination trust and intention to travel: A medical tourism perspective. Journal of Destination Marketing and Management, 5(3), 192-201. https://doi.org/10.1016/j.jdmm.2015.12.005

Ali, H. (2019). Building Repurchase Intention and Purchase Decision: Brand Awareness and Brand Loyalty Analysis (Case Study Private Label Product in Alfamidi Tangerang). Saudi Journal of Humanities and Social Sciences. https://doi.org/10.36348/sjhss.2019.v04i09.009

Ali, H., Limakrisna, N., \& Jamaluddin, S. (2016). Model of customer satisfaction: The empirical study at Bri in Jambi. International Journal of Applied Business and Economic Research.

Ali, H., \& Limakrisna, N. (2013). Metodologi Penelitian (Petunjuk Praktis untuk Pemecahan Masalah Bisnis, Penyusunan Skripsi, Tesis, dan Disertasi). Deeppublish: Yogyakarta.

Ali, H., \& Mappesona, H. (2016). Build brand image: Analysis Service Quality and Product Quality (case study at Giant Citra Raya). International Journal of Economic Research.

Ali, H., Narulita, E., \& Nurmahdi, A. (2018). Saudi Journal of Business and Management Studies ( SJBMS ) The Influence of Service Quality, Brand Image and Promotion on Purchase Decision at MCU Eka Hospital. Business and Management Studies. https://doi.org/10.21276/sjbms.2018.3.1.12

Bataineh, A. Q. (2015). The Impact of Perceived e-WOM on Purchase Intention: The Mediating Role of Corporate Image. International Journal of Marketing Studies, 7(1), 126-137. https://doi.org/10.5539/ijms.v7n1p126

Bhandari, M., \& Rodgers, S. (2018). What does the brand say? Effects of brand feedback to negative eWOM on brand trust and purchase intentions. International Journal of Advertising, 37(1), 125-141. https://doi.org/10.1080/02650487.2017.1349030

Bulut, Z. A., \& Karabulut, A. N. (2018). Examining the role of two aspects of eWOM in online repurchase intention: An integrated trust-loyalty perspective. Journal of Consumer Behaviour, 17(4), 407-417. https://doi.org/10.1002/cb.1721

Cheong \&Jang. (2008). Determinants of Internet Usage in Ghanaian Hotels : The Case of the Greater Accra Region ( GAR ) Determinants of Internet Usage in Ghanaian Hotels : The Case of the Greater Accra Region ( GAR ). Journal of Hospitality \& Leisure Marketing, 15(3), 37-41. https://doi.org/10.1300/J150v15n03

Desfiandi, A., Desfiandi, A., \& Ali, H. (2017). Composite Stock Price Index (IHSG) Macro Factor in Investment in Stock (Equity Funds). International Journal of Economics and Financial Issues.

Erkan, I., \& Evans, C. (2016). The influence of eWOM in social media on consumers' purchase intentions: An extended approach to information adoption. Computers in Human Behavior, 61, 47-55. https://doi.org/10.1016/j.chb.2016.03.003

Farivar, S., Turel, O., \& Yuan, Y. (2017). A trust-risk perspective on social commerce use: an examination of the biasing role of habit. Internet Research, 27(3), 586-607. https://doi.org/10.1108/IntR-06-2016-0175

Firmansyah, N., \& Ali, H. (2019). Consumer Trust Model : The Impact of Satisfaction and EService Quality toward Repurchase Intention in E-Commerce. 6256, 552-559. https://doi.org/10.21276/sjhss.2019.4.8.4

Gunawan, D. D., \& Huarng, K. H. (2015). Viral effects of social network and media on consumers' purchase intention. Journal of Business Research, 68(11), 2237-2241. https://doi.org/10.1016/j.jbusres.2015.06.004 
Han, B., Kim, M., \& Lee, J. (2018). Exploring consumer attitudes and purchasing intentions of cross-border online shopping in Korea. Journal of Korea Trade, 22(2), 86-104. https://doi.org/10.1108/JKT-10-2017-0093

Ho, S. M., Ocasio-Velázquez, M., \& Booth, C. (2017). Trust or consequences? Causal effects of perceived risk and subjective norms on cloud technology adoption. Computers and Security, 70, 581-595. https://doi.org/10.1016/j.cose.2017.08.004

Indarsin, T., \& Ali, H. (2017). Attitude toward Using m-Commerce: The Analysis of Perceived Usefulness Perceived Ease of Use, and Perceived Trust: Case Study in Ikens Wholesale Trade, Jakarta - Indonesia. Saudi Journal of Business and Management Studies. https://doi.org/10.21276/sjbms.2017.2.11.7

Indrajaya, H. S., \& Al, H. (2017). Shopping Analysis in on Line Shop with Young People. The International Journal of Social Sciences and Humanities Invention, 4(7), 37973802. https://doi.org/10.18535/ijsshi/v4i8.17

Jalilvand, M. R., Nasrolahi Vosta, L., Kazemi Mahyari, H., \& Khazaei Pool, J. (2017). Social responsibility influence on customer trust in hotels: mediating effects of reputation and word-of-mouth. Tourism Review, 72(1), 1-14. https://doi.org/10.1108/TR-092016-0037

Journal, A. M., \& Ali, H. (2017). Scholars Bulletin Analysis of the Company Image and Service Quality through Customer Satisfaction to Customer Loyalty ( A Field Research in PT . Nusantara Water Centre ). 149-158. https://doi.org/10.21276/sb.2017.3.3.10

Kamalul Ariffin, S., Mohan, T., \& Goh, Y. N. (2018). Influence of consumers' perceived risk on consumers' online purchase intention. Journal of Research in Interactive Marketing, 12(3), 309-327. https://doi.org/10.1108/JRIM-11-2017-0100

Kazmi, A., \& Mehmood, Q. S. (2016). The effect of electronic word of mouth communication and brand image on purchase intention: A case of consumer electronics in Haripur, Pakistan. Management Science Letters, 6, 409-508. https://doi.org/10.5267/j.msl.2016.5.003

Kristiani, E., B, C. Y., \& Wang, Y. (2019). for Real-Time Data Streaming Processing on the Edge Computing Architecture (Vol. 1). Springer International Publishing. https://doi.org/10.1007/978-3-030-06158-6

Larasetiati, M., \& Ali, H. (2019). Model of Consumer Trust: Analysis of Perceived Usefulness and toward Repurchase Intention in Online Travel Agent. Journal of Economics and Finance, 3(8), 350-357. https://doi.org/10.21276/sjef.2019.3.8.5

Lecturer, M. H. (2016). Impact of website design and Perceived Risk, Internet trust on the Consumer Purchase intention in FOREX Market. 2(2).

Lee, W. I., Cheng, S. Y., \& Shih, Y. T. (2017). Effects among product attributes, involvement, word-of-mouth, and purchase intention in online shopping. Asia Pacific Management Review, 22(4), 223-229. https://doi.org/10.1016/j.apmrv.2017.07.007

Liu, D., \& Guo, X. (2017). Can trust and social benefit really help? Empirical examination of purchase intentions for wearable devices. Information Development, 33(1), 43-56. https://doi.org/10.1177/0266666916635724

M, A., \& Ali, H. (2017). MODEL KEPUASAN PELANGGAN: ANALISIS KUALITAS PRODUK DAN KUALITAS LAYANAN TERHADAP CITRA MEREK PADA GIANT CITRA RAYA JAKARTA. Jurnal Manajemen. https://doi.org/10.24912/jm.v21i3.254

Marriott, H. R., \& Williams, M. D. (2018). Exploring consumers perceived risk and trust for mobile shopping: A theoretical framework and empirical study. Journal of Retailing and Consumer Services, 42(January), 133-146. 
https://doi.org/10.1016/j.jretconser.2018.01.017

Matute, J., Polo-Redondo, Y., \& Utrillas, A. (2016). The influence of EWOM characteristics on online repurchase intention. Online Information Review, 40(7), 1090-1110. https://doi.org/10.1108/oir-11-2015-0373

Mosunmola, A., Adegbuyi, O., Kehinde, O., Agboola, M., \& Olokundun, M. (2019). Percieved value dimensions on online shopping intention: The role of trust and culture. Academy of Strategic Management Journal, 18(1), 1-20.

Novansa, H., \& Ali, H. (1926). Purchase Decision Model: Analysis of Brand Image, Brand Awareness and Price (Case Study SMECO Indonesia SME products). Saudi Journal of Humanities and Social Sciences. https://doi.org/10.21276/sjhss

Pappas, I. O. (2018). User experience in personalized online shopping: a fuzzy-set analysis. European Journal of Marketing, 52(7-8), 1679-1703. https://doi.org/10.1108/EJM10-2017-0707

Pappas, N. (2016). Marketing strategies, perceived risks, and consumer trust in online buying behaviour. Journal of Retailing and Consumer Services, 29, 92-103. https://doi.org/10.1016/j.jretconser.2015.11.007

Park, J., Amendah, E., Lee, Y., \& Hyun, H. (2019). M-payment service: Interplay of perceived risk, benefit, and trust in service adoption. Human Factors and Ergonomics In Manufacturing, 29(1), 31-43. https://doi.org/10.1002/hfm.20750

Pudaruth, S., \& Nursing, R. K. (2017). Exploring the Determining Factors Influencing Online Purchase Behaviour Among Consumers in Emerging Economies: a Case of Mauritius. International Journal of Arts \& Science, 10(01), 1-22.

Setyadi, D. A. (2017). Build Customer Loyalty with CRM and Brand Image (Case Study on Giant Citra Raya). IOSR Journal of Business and Management, 19(01), 35-42. https://doi.org/10.9790/487x-1901043542

Silva, J., Pinho, J. C., Soares, A., \& Sá, E. (2019). Antecedents of online purchase intention and behaviour: Uncovering unobserved heterogeneity. Journal of Business Economics and Management, 20(1), 131-148. https://doi.org/10.3846/jbem.2019.7060

Suharjadi, P. D., Pascasarjana, P., Manajemen, M., \& Mercu, U. (2017). Jurnal SWOT, Volume VII , No 3 , September 2017 Jurnal SWOT, Volume VII , No 3 , September 2017. $\operatorname{VII}(3), 629-645$.

Toto Handiman, U., \& Ali, H. (2019). The Influence of Brand Knowledge and Brand Relationship On Purchase Decision Through Brand Attachment. In International Journal of Business Marketing and Management (IJBMM).

Wingate, N. (2019). The Influence of Fake Reviews on Consumer Perceptions of Risks and Purchase Intentions. Journal of Marketing Development and Competitiveness, 13(3), 133-144. https://doi.org/10.33423/jmdc.v13i3.2244

Yang, Q., Pang, C., Liu, L., Yen, D. C., \& Michael Tarn, J. (2015). Exploring consumer perceived risk and trust for online payments: An empirical study in China's younger generation. Computers in Human Behavior, 50, 9-24. https://doi.org/10.1016/j.chb.2015.03.058

Yu, C. C., Lin, P. J., \& Chen, C. S. (2013). How brand image, country of origin, and selfcongruity influence internet users' purchase intention. Social Behavior and Personality, 41(4), 599-611. https://doi.org/10.2224/sbp.2013.41.4.599

Zhao, J. Di, Huang, J. S., \& Su, S. (2019). The effects of trust on consumers' continuous purchase intentions in $\mathrm{C} 2 \mathrm{C}$ social commerce: A trust transfer perspective. Journal of Retailing and Consumer Services, 50(January), 42-49. https://doi.org/10.1016/j.jretconser.2019.04.014 